\title{
Sunlight-Driven Dehydrogenative Oxidation Photocatalysis by a Mononuclear Complex Acting as both Chromophore and Catalyst
}

\author{
Francisca R. Rocha, ${ }^{\oplus * a}{ }^{*}$ Weizhong Chen, ${ }^{a}$ Brian L. Scott ${ }^{a}$ and Reginaldo C. Rocha ${ }^{\oplus *, a}$
}

${ }^{a}$ Los Alamos National Laboratory, Los Alamos, NM 87545, USA

\begin{abstract}
Under simulated solar irradiation in the visible spectral region, the catalytically active $\mathrm{Ru}^{\mathrm{IV}}$-oxo species $[\mathrm{Ru}(\mathrm{O})(\mathrm{bpy})(\mathrm{tppz})]^{2+}$ (tppz $=$ tetrapyridylpyrazine, a strongly $\pi$-accepting tridentate $N, N, N$-ligand) is produced directly from a single metal-to-ligand charge-transfer (MLCT) photoexcitation of the resting $\mathrm{Ru}^{\mathrm{II}}$-aquo complex $\left[\mathrm{Ru}\left(\mathrm{H}_{2} \mathrm{O}\right)(\mathrm{bpy})(\mathrm{tppz})\right]^{2+}$ in aqueous media containing an electron acceptor. This photoinduced path to 2-electron/2-proton activation of a mononuclear catalyst (i.e., without a paired chromophoric unit) is enabled by the thermodynamic instability of the intermediate $\mathrm{Ru}^{\mathrm{III}}$-hydroxo species $[\mathrm{Ru}(\mathrm{OH})(\mathrm{bpy})(\mathrm{tppz})]^{2+}$, which promptly disproportionates into the $\mathrm{Ru}^{\mathrm{IV}}$-oxo and $\mathrm{Ru}^{\mathrm{II}}$-aquo states as electrochemically observed by cyclic and pulse voltammetries in a wide range of $\mathrm{pH}$. The proton-coupled multielectron photocatalytic capability of the complex in neutral aqueous solutions, at room conditions, was demonstrated through the dehydrogenative oxidation of benzyl alcohol into benzaldehyde with a product selectivity of about $100 \%$. The performance of this mononuclear complex acting as chromophore/catalyst is comparable to that of the previously reported dinuclear complex $\left[(\operatorname{tpy}) \mathrm{Ru}(\mathrm{tppz}) \mathrm{Ru}\left(\mathrm{H}_{\mathrm{x}} \mathrm{O}\right)(\mathrm{bpy})\right]^{4+}$. In addition to the characterization of redox and spectroscopic properties for the $[R u(L)(b p y)(t p p z)]^{n+}$ derivatives with $\mathrm{L}=\mathrm{Cl}^{-}$or $\mathrm{H}_{\mathrm{x}} \mathrm{O}$, structural analysis of the precursor chloro complex $[\mathrm{RuCl}(\mathrm{bpy})(\mathrm{tppz})]\left(\mathrm{PF}_{6}\right)$ was also performed by single-crystal X-ray diffraction in this work.
\end{abstract}

Keywords: photochemistry, photooxidation, proton-coupled electron transfer, ruthenium, solar catalysis

\section{Introduction}

A crucial challenge to renewable energy technologies based on solar fuels has been the development of molecular photocatalysts that can efficiently carry out complex multi-electron/multi-proton reactions using sunlight as the only energy input. ${ }^{1-5}$ A parallel issue of relevance to the intertwined energy and environmental chemistries has been the utilization of water not only as the ideal replacement for undesirable organic solvents but also as the ultimate source of oxygen and protons/electrons in "green" photosynthetic reaction schemes. ${ }^{6-8}$ Owing to the intrinsically endergonic nature and mechanistic complexity of the underlying chemical bond breaking/ forming reactions, it has been widely recognized that (photo)catalysis science is at the heart of this global problem and can play a central role in overcoming the greatest technical hurdles to achieve an envisioned solar chemical industry. ${ }^{1,4}$

*e-mail: franrein@lanl.gov; rcrocha@lanl.gov

Dedicated to Prof Henrique Eisi Toma on the occasion of his $70^{\text {th }}$ birthday.
Significant advances have been made in the area of homogeneous photocatalysis in water by supramolecular assemblies of Ru complexes. ${ }^{9-15}$ From our interest in this area, we have previously introduced alcohol-oxidation photocatalysts based on ligand-bridged dinuclear complexes (which were termed $\mathrm{Ru}_{\text {chromophore }}-\mathrm{Ru}_{\text {catalyst }}$ dyads) of the type $\left[(\text { tpy }) \mathrm{Ru}\left({ }_{N, N, N} \mathrm{~L}-\mathrm{L}_{N, N, N}\right) \mathrm{Ru}\left(\mathrm{H}_{2} \mathrm{O}\right)(\text { bpy })\right]^{4+}$ (where tpy is terpyridine and bpy is 2,2 '-bipyridine). ${ }^{16,17}$ As a proof-ofconcept, we demonstrated that such dyads can perform the visible sunlight-driven oxidation of organic substrates, such as the conversion of alcohols into the corresponding aldehyde or ketone products, with ca. 100\% selectivity and tens of catalytic turnover cycles/hour. As with water-splitting catalysis, it was conceptualized that the protons and electrons released in the photoanodic half-reaction (i.e., $\mathrm{R}^{1} \mathrm{CH}(-\mathrm{OH})$ $\left.\mathrm{R}^{2}+2 h v \rightarrow \mathrm{R}^{1} \mathrm{C}(=\mathrm{O}) \mathrm{R}^{2}+2 \mathrm{H}^{+}+2 \mathrm{e}^{-}\right)$can be subsequently recombined to form $\mathrm{H}_{2}$ at a cathodic terminal such as in a two-compartment photoelectrochemical cell (Scheme 1).

The photocatalytic activity of chromophore-catalyst dyads was achieved by coupling the single-photon visible absorption/excitation of a photosensitizer with the multi-electron/multi-proton transfer reactivity of 
a catalytic center. The widespread utilization of Rupolypyridyl derivatives as chromophoric and catalytic components in such assemblies is due to their wellknown capability for $(i)$ strong visible-light absorption with formation of metal-to-ligand, photoexcited charge-transfer states that can undergo long-lived charge separation followed by photochemical electrontransfer reactions, and (ii) flexible redox chemistry that allows for effective proton management through stepwise proton-coupled electron transfer processes $\left(\mathrm{O}=\mathrm{M}^{\mathrm{n}+2} \stackrel{\mathrm{H}^{+}, \mathrm{e}^{-}}{\rightleftharpoons} \mathrm{HO}-\mathrm{M}^{\mathrm{n}+1} \stackrel{\mathrm{H}^{+}, \mathrm{e}^{-}}{\rightleftharpoons} \mathrm{H}_{2} \mathrm{O}-\mathrm{M}^{\mathrm{n}+}\right)$ with buildup of multiple oxidizing equivalents at a single metal-centered chemical site. In exploratory studies, the acceptor is typically a suitable sacrificial agent; this surrogate can then be replaced by an appropriate metal-oxide semiconductor (e.g., $\left.\mathrm{TiO}_{2}\right)^{18,19}$ in a compartmentalized, fully integrated anodic/cathodic solar cell design (Scheme 1).

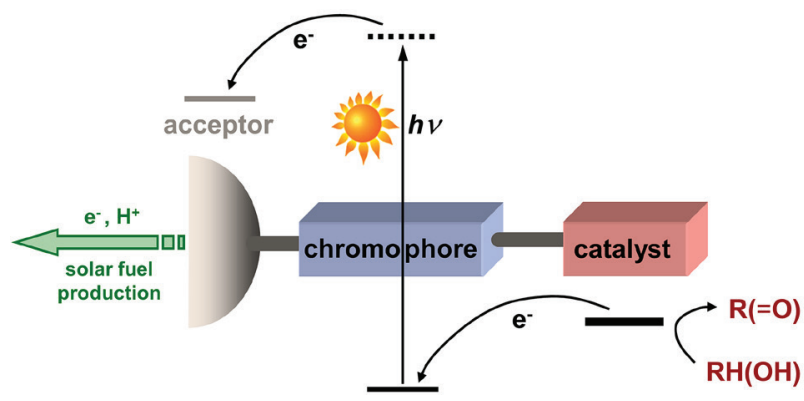

Scheme 1. Illustrative integration of solar photooxidation of organics into a complete photoelectrochemical device with the conceptualized reductive production of a fuel (dihydrogen or hydrocarbons) at a cathodic terminal. In this study, a "monad" is explored to perform the roles of both chromophore and catalyst units.

However, in one of our aforementioned dinuclear complexes, ${ }^{17}$ we found that the Ru centers were too strongly coupled by the electronically delocalized bridging ligand 2,3,5,6-tetrakis(2-pyridyl)pyrazine (tppz) and therefore lacked the defined structural and electronic boundaries to be denoted a modular $\mathrm{Ru}_{\text {chromophore }}-\mathrm{Ru}_{\text {catalyst }}$ "dyad". Our studies showed that electron delocalization over the strongly $\pi$-accepting tppz bridge led to inferior photocatalytic performance relative to the weakly coupled, supramolecular dyads with a single covalent bond linking the chromophore and catalyst building blocks. ${ }^{16}$ Albeit lessened, the observed photocatalytic activity of the delocalized complex [(tpy) $\mathrm{Ru}($ tppz $\left.) \mathrm{Ru}\left(\mathrm{H}_{2} \mathrm{O}\right)(\mathrm{bpy})\right]^{4+}$ triggered our motivation to further explore the extreme case of "single-core" behavior, as represented by its mononuclear $\left[\mathrm{Ru}\left(\mathrm{H}_{2} \mathrm{O}\right)(\mathrm{bpy})(\mathrm{tppz})\right]^{2+}$ moiety (Scheme 2). For the purpose of this investigation, we selected benzyl alcohol as representative of the substrates that previously yielded significantly more (relative to aliphatics) of the corresponding oxidized carbonyl product, ${ }^{17}$ a transformation of relevance to industrial organic processes. ${ }^{20-22}$

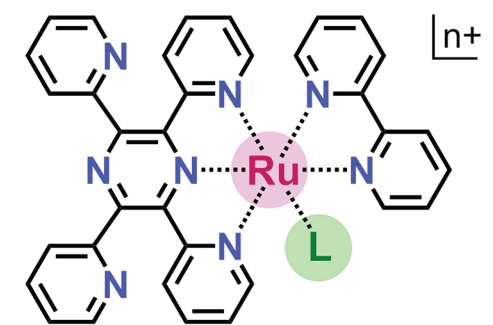

$$
\begin{aligned}
& \mathrm{L}=\mathrm{Cl}^{-}, \mathrm{n}=1 \\
& \mathrm{~L}=\mathrm{H}_{2} \mathrm{O}, \mathrm{n}=2
\end{aligned}
$$

Scheme 2. The mononuclear complex $[\mathrm{Ru}(\mathrm{L})(\mathrm{bpy})(\mathrm{tppz})]^{\mathrm{n}+}$.

\section{Experimental}

\section{Materials and synthesis}

As synthetic precursors of dinuclear species in our previous studies, the mononuclear chloro and aquo complexes, $[\mathrm{RuCl}(\mathrm{bpy})(\mathrm{tppz})]\left(\mathrm{PF}_{6}\right)$ and $\left[\mathrm{Ru}\left(\mathrm{H}_{2} \mathrm{O}\right)(\mathrm{bpy})(\mathrm{tppz})\right]\left(\mathrm{CF}_{3} \mathrm{SO}_{3}\right)_{2}$, were isolated and analytically characterized as previously described in detail. ${ }^{17}$ All reagents and solvents were analytical grade and supplied in the highest purity available from Fisher Scientific (Pittsburgh, PA, USA). Aqueous solutions were prepared using deionized water from a Nanopure system. Standard phosphate buffer solutions at $\mathrm{pH} 6.8(0.1 \mathrm{M})$ were prepared from the sodium phosphate monobasic and dibasic salts $\left(\mathrm{NaH}_{2} \mathrm{PO}_{4} / \mathrm{Na}_{2} \mathrm{HPO}_{4}\right)$. In $\mathrm{pH}$-dependent measurements, the $\mathrm{pH}$ of solutions was buffered at an ionic strength of $0.1 \mathrm{M}$ with the Britton-Robinson (BR) multi-buffer and the $\mathrm{pH}$ of the samples was finely adjusted by controlled microvolumetric additions of $3.0 \mathrm{M}$ sodium hydroxide or triflic acid solutions.

\section{Characterization methods}

${ }^{1} \mathrm{H}$ nuclear magnetic resonance (NMR) spectra were collected at $298 \mathrm{~K}$ using a Bruker DRX-400 instrument. Gas chromatography-mass spectrometry (GC-MS) was performed as described below, in the "Photocatalysis" subsection. UV-Vis absorption spectra were recorded on a Cary 300 spectrophotometer. A CHI 700E potentiostat was used in electrochemical experiments. In both cyclic voltammetry (CV) and differential pulse voltammetry (DPV), the standard three-electrode setup consisted of a glassy carbon working electrode, a Pt wire auxiliary electrode, and a saturated calomel electrode (SCE) as the reference electrode. Samples were purged with an inert gas stream ( $\mathrm{Ar}$ ). The $\mathrm{pH}$ of aqueous solutions was measured with a Thermo Orion 250A+ digital $\mathrm{pH}$ meter calibrated within the ranges of interest using appropriate standard buffers. 


\section{X-ray crystallography}

A crystal of the compound was mounted in a nylon cryoloop from Paratone-N oil under argon gas flow. The data were collected on a Bruker D8 diffractometer, with APEX II charge-coupled-device (CCD) detector, and a Bruker Kryoflex low-temperature device. The instrument was equipped with graphite monochromatized Mo K $\alpha$ X-ray source $(\lambda=0.71073 \AA)$, and a $0.5 \mathrm{~mm}$ monocapillary. A hemisphere of data was collected using $\omega$ scans, with 10 -second frame exposures and $0.5^{\circ}$ frame widths. Data collection and initial indexing and cell refinement were handled using APEX II software. ${ }^{23}$ Frame integration, including Lorentz-polarization corrections, and final cell parameter calculations were carried out using SAINT+ software; ${ }^{24}$ data were corrected for absorption using redundant reflections and the SADABS program. ${ }^{25}$ The structure was solved using direct methods and difference Fourier techniques, with idealized hydrogen positions riding on atoms of attachment. The final refinement included anisotropic temperature factors on all non-hydrogen atoms. Structure solution, refinement, and graphics were performed using the SHELXS/SHELXL/SHELXTL suite. ${ }^{26}$ Detailed crystal and refinement parameters are provided in Supplementary Information (SI) section (Table S1).

\section{Photocatalysis}

In catalytic experiments, the same reaction time and conditions from previous studies on dinuclear species were used exactly as reported ${ }^{17}$ for direct comparison of results. Specifically, a sealed quartz vial containing $5.0 \mathrm{~mL}$ of $\mathrm{O}_{2}$-free buffered solution ( $\mathrm{pH} 6.8$ ) with $0.02 \mathrm{mM} \mathrm{Ru}$ complex (photocatalyst), $10 \mathrm{mM}$ substrate (alcohols), and $20 \mathrm{mM}\left[\mathrm{Co}\left(\mathrm{NH}_{3}\right)_{5} \mathrm{Cl}\right] \mathrm{Cl}_{2}$ (acceptor) was irradiated for $24.0 \mathrm{~h}$, a period during which the mixture was kept under stirring. Control tests were performed at the same conditions but in the absence of either light or catalyst or acceptor. All experiments were carried out at room temperature and pressure. A Newport/Oriel solar simulator equipped with a digital arc lamp power supply and a Xe lamp (300 W) in line with AM $1.5 \mathrm{G}$ and UV cut-off filters to supply the simulated sunlight irradiation above $400 \mathrm{~nm}$. The incident irradiance was measured with an International Light Technologies ILT1400-A radiometer/photometer equipped with a calibrated silicon photodiode detector (ILT model SEL033/ QNDS2/W; 200-1100 nm). Final efficiency and selectivity of reaction products were quantitatively characterized by ${ }^{1} \mathrm{H}$ NMR assays from the ratio of integrated peak intensity of product to that of corresponding substrate (in this case, $\mathrm{D}_{2} \mathrm{O}$ was used instead of $\mathrm{H}_{2} \mathrm{O}$ as solvent); qualitative comparative analyses were made by GC using an Agilent 213-7333 instrument equipped with a DB-WAXETER column and a flame ionization detector with $\mathrm{He}$ as carrier gas. The oven temperature started at $50{ }^{\circ} \mathrm{C}$ for $5 \mathrm{~min}$, then ramped to $250{ }^{\circ} \mathrm{C}\left(50{ }^{\circ} \mathrm{C} \mathrm{min}-1\right)$ and held for $25 \mathrm{~min}$. The procedures for sample injection were substrate specific. For benzyl alcohol, the reaction suspension $(5 \mathrm{~mL})$ was filtered and extracted by dichloromethane ( $3 \mathrm{~mL}$, three times); the organic phase was collected, concentrated to about $2 \mathrm{~mL}$, and a $2 \mu \mathrm{L}$-sample of the solution was injected into the gas chromatograph.

\section{Computational methods}

Density functional theory (DFT) calculations were performed with the Gaussian 16 program. ${ }^{27}$ The Becke, 3-parameter, Lee-Yang-Parr (B3LYP) ${ }^{28,29}$ functional with the $\mathrm{SDD}^{30}$ relativistic effective core potential and associated basis set for $\mathrm{Ru}$ and the 6-31G(d) basis set ${ }^{31,32}$ for all other elements, a methodology that has consistently shown adequate performance in structural and electronic characterization of closely related systems. ${ }^{33,34}$ To better account for specific solvent effects on the $\mathrm{Ru}-\mathrm{OH}_{2}$ moiety, ${ }^{33,34}$ two solvent water molecules were explicitly added to the immediate surrounding microenvironment of the metalbound $\mathrm{H}_{2} \mathrm{O}$ (i.e., one explicit solvent interaction per $\mathrm{H}$ of the coordinated water ligand, $\mathrm{H}_{2} \mathrm{O} \cdots \mathrm{H}-\mathrm{O}_{\mathrm{Ru}}-\mathrm{H} \cdots \mathrm{OH}_{2}$ ) and the overall supramolecular structure was freely optimized without any constraint. Following full geometry optimization, vibrational frequencies were computed at the same level of theory to verify the nature of all stationary points as true minima with no imaginary frequencies. The structure of the lowest-energy metal-to-ligand chargetransfer ( ${ }^{3} \mathrm{MLCT}$ ) excited state was also fully optimized prior to molecular orbital and spin density analysis. The electronic excitation spectra in the UV/Vis region were obtained by time-dependent DFT (TD-DFT) ${ }^{35,36}$ calculations using the same functional/basis sets in conjunction with the C-PCM solvation model ${ }^{37,38}$ to further account for the solvent (water) environment. Graphical visualization of molecular structures and 3D surface plots were generated with GaussView $6 .{ }^{39}$

\section{Results and Discussion}

\section{X-ray structural analysis}

The chloro complex $[\mathrm{RuCl}(\mathrm{bpy})(\mathrm{tppz})]\left(\mathrm{PF}_{6}\right)$ was prepared and characterized as described in our earlier study, ${ }^{17}$ where it was used as intermediate in one of the routes to the synthesis of the dinuclear complex $[($ tpy $) \mathrm{Ru}(\mathrm{tppz}) \mathrm{RuCl}(\mathrm{bpy})]\left(\mathrm{PF}_{6}\right)_{3}$. In the present work, 
however, the structure of this complex was determined and analyzed by X-ray crystallography. Single crystals were grown by slow diffusion of diethyl ether into acetonitrile solutions of $[\mathrm{RuCl}(\mathrm{bpy})(\mathrm{tppz})]\left(\mathrm{PF}_{6}\right)$. This hexafluorophosphate salt of the complex crystallized in the monoclinic $\left(P 2_{1} / \mathrm{c}\right)$ space group. The Oak Ridge thermal ellipsoid plot (ORTEP) diagram is shown in Figure 1 and selected structural data are summarized in Table 1. Detailed crystallographic data, collection/refinement parameters, and a complete list of all bond distances and angles are included in the SI section (Tables S1-S5).

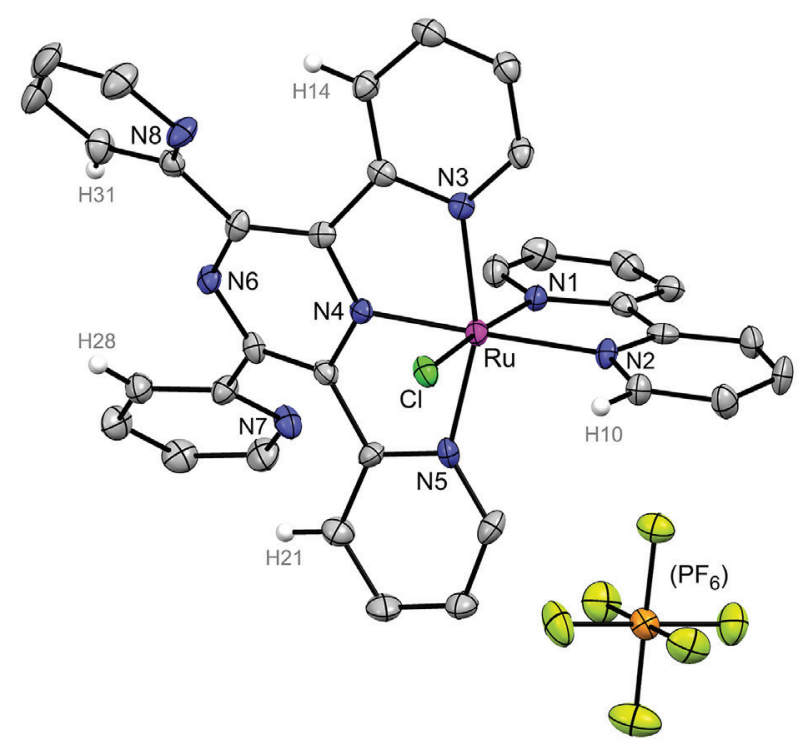

Figure 1. Single-crystal X-ray structure of $[\operatorname{RuCl}(b p y)(\operatorname{tppz})]$ $\left(\mathrm{PF}_{6}\right) \cdot \mathrm{CH}_{3} \mathrm{CN}$. The acetonitrile molecule from the solvent is not shown. Also omitted for clarity are the $\mathrm{H}$ atoms, except for those involved in short contacts as discussed in the text. Thermal ellipsoid plots are drawn at the $50 \%$ probability level.

The $[\mathrm{RuCl}(\mathrm{bpy})(\mathrm{tppz})]\left(\mathrm{PF}_{6}\right)$ complex has a distorted octahedral geometry at the Ru center due to the restricted bite angle of the meridionally coordinated tridentate tppz ligand. The N3-Ru-N5 angle of $159.75(14)^{\circ}$ is similar to those of the related dinuclear complexes [(bpy)ClRu(tppz)RuCl(bpy)]( $\left.\mathrm{PF}_{6}\right)_{2}$ and [(tpy)Ru(tppz) $\mathrm{RuCl}(\mathrm{bpy})]\left(\mathrm{PF}_{6}\right)_{3}\left(159.4-160.6^{\circ}\right) .{ }^{17,40}$ The bidentate bpy ligand has a cis configuration, with the N1 atom arranged trans to the chloride ligand in a nearly linear $\mathrm{N}-\mathrm{Ru}-\mathrm{Cl}$ fashion $\left(172.42(10)^{\circ}\right)$ and with a N1-Ru-N2 angle of $78.24(14)^{\circ}$. The significant deviations from idealized straight and right angles are typical of such "octahedral" structures. ${ }^{40-42}$ The Ru center and atoms N1, N2, N4, and $\mathrm{Cl}$ form an equatorial plane with a maximum deviation of $0.035(3) \AA$. The mean planes of the bpy rings are approximately coplanar, with a dihedral angle of $8.2(2)^{\circ}$. In contrast, a significant distortion from planarity is observed for the tppz moiety, which adopts a significantly twisted
Table 1. Selected crystallographic bond distances and angles for $[\mathrm{RuCl}(\mathrm{bpy})(\mathrm{tppz})]\left(\mathrm{PF}_{6}\right) \cdot \mathrm{CH}_{3} \mathrm{CN}$

\begin{tabular}{|c|c|c|c|}
\hline \multicolumn{2}{|c|}{ Distance / Å } & \multicolumn{2}{|c|}{ Angle / degree } \\
\hline $\mathrm{Ru} 1-\mathrm{Cl1}$ & $2.4008(12)$ & N1-Ru1-Cl1 & $172.42(10)$ \\
\hline Ru1-N1 & $2.039(4)$ & N1-Ru1-N2 & $78.24(14)$ \\
\hline Ru1-N2 & $2.094(4)$ & N1-Ru1-N3 & $90.78(15)$ \\
\hline Ru1-N3 & $2.045(4)$ & N1-Ru1-N4 & $95.01(15)$ \\
\hline Ru1-N4 & $1.939(4)$ & N1-Ru1-N5 & $92.29(15)$ \\
\hline Ru1-N5 & $2.053(4)$ & N2-Ru1-Cl1 & $94.48(10)$ \\
\hline N4-N6 & $2.689(5)$ & N2-Ru1-N3 & $102.14(14)$ \\
\hline C5-C6 & $1.467(6)$ & N2-Ru1-N4 & $173.14(14)$ \\
\hline C15-C16 & $1.473(6)$ & N2-Ru1-N5 & $98.09(14)$ \\
\hline C17-C30 & $1.486(6)$ & N3-Ru1-Cl1 & $88.71(11)$ \\
\hline $\mathrm{C} 18-\mathrm{C} 29$ & $1.483(6)$ & N3-Ru1-N4 & $79.00(15)$ \\
\hline $\mathrm{C} 19-\mathrm{C} 20$ & $1.463(6)$ & N3-Ru1-N5 & $159.75(14)$ \\
\hline $\mathrm{Cl} 1 \cdots \mathrm{H} 10$ & 2.778 & N4-Ru1-Cl1 & $92.31(11)$ \\
\hline N6 $\cdots H 28$ & 2.602 & N4-Ru1-N5 & $80.79(15)$ \\
\hline N6 $\cdots H 31$ & 2.473 & N5-Ru1-Cl1 & $90.80(11)$ \\
\hline $\mathrm{N} 7 \cdots \mathrm{H} 21$ & 2.586 & Ru1-N4-N6 & $173.40(19)$ \\
\hline N8 $\cdots H 14$ & 2.410 & N7-N6-N8 & $166.34(13)$ \\
\hline
\end{tabular}

conformation across the central pyrazine ring with an average torsion angle of $52.1(2)^{\circ}$ between the mean planes of adjacent pyridyl rings. The average displacement of the four carbon atoms relative to the mean plane of pyrazine is 0.184(5) $\AA$, and the average dihedral angle formed between the intersection of pyridyl planes with the pyrazine mean plane is $26.4(2)^{\circ}$.

For the tppz coordination, the mean $\mathrm{Ru}-\mathrm{N}$ distances involving the outer $\mathrm{N} 3$ and $\mathrm{N} 5$ atoms trans to each other are 2.045(4) and 2.053(4) $\AA$, whereas the bond distance involving the central N4 is much shorter (1.939(4) ̊) as a result of the geometric constraint imposed by the tridentate mer-arrangement as well as the much stronger $\pi$-acceptor ability of the pyrazine-centered bridge. ${ }^{43,44}$ For bpy, the Ru-N distance is 2.094(4) for N2 but only 2.039(4) $\AA$ for $\mathrm{N} 1$, reflecting the increased $\mathrm{Ru}^{\mathrm{II}} \rightarrow \mathrm{N}_{\text {bpy }}$ $\pi$-backbonding interaction at the coordinating atom trans to the $\pi$-donor $\mathrm{Cl}^{-}$ligand. The $\mathrm{Ru}-\mathrm{Cl}$ distance of $2.4008(12) \AA$ is essentially the same as that observed for [(tpy)Ru(tppz)RuCl(bpy)] $\left(\mathrm{PF}_{6}\right)_{3}(2.401 \AA) \cdot{ }^{17}$ In addition to the common weak interactions between molecules in the crystal, multiple intramolecular contacts (i.e., distances shorter than the sum of van der Waals radii) are found in the structure of $[\mathrm{RuCl}(\mathrm{bpy})(\mathrm{tppz})]\left(\mathrm{PF}_{6}\right)$. The $\mathrm{H} \cdots \mathrm{Cl}$ contact of $2.778 \AA$ Anvolving the hydrogen of the nearest $\mathrm{CH}$ from a bpy ring $(\mathrm{C} 10)$ is similar to those for a number of structures containing the $\left\{\left(\mathrm{L}_{N, N, N}\right) \mathrm{RuCl}(\right.$ bpy $\left.)\right\}$ fragment. ${ }^{17,40,42}$ Owing 
to the short $\mathrm{N} \cdots \mathrm{H}$ contacts (in the range of 2.41-2.60 $\AA$ ) between N6, N7, N8 and their nearest hydrogen atoms from adjacent rings ( $\mathrm{H} 28 \cdots \mathrm{N} 6 \cdots \mathrm{H} 31, \mathrm{~N} 7 \cdots \mathrm{H} 21$, and $\mathrm{N} 8 \cdots \mathrm{H} 14)$, the outer uncoordinated tppz pyridyl rings adopt an optimal, flipped conformation relative to its mer-coordinated form (Figure 1 and Table 1).

\section{Electrochemistry and electronic spectroscopy}

From cyclic voltammetry, the observed potential $\left(\mathrm{E}_{1 / 2}\right)$ for the reversible oxidation $\left[\mathrm{Ru}^{\mathrm{II}} \mathrm{Cl}(\mathrm{bpy})(\mathrm{tppz})\right]^{+} /$ $\left[\mathrm{Ru}^{\mathrm{III}} \mathrm{Cl}(\mathrm{bpy})(\text { tppz) }]^{2+}\right.$ in acetonitrile $\left(0.1 \mathrm{M}^{n} \mathrm{Bu}_{4} \mathrm{NPF}_{6}\right)$ is $0.93 \mathrm{~V}$ vs SCE. The significantly more positive potential compared to that of $[\mathrm{RuCl} \text { (bpy)(tpy) }]^{+}(0.81 \mathrm{~V}$ vs SCE at the same experimental conditions $)^{16}$ reflects the stronger $\pi$-acceptor character of tppz relative to tpy.

The aquo species as a triflate salt, $\left[\mathrm{Ru}\left(\mathrm{H}_{2} \mathrm{O}\right)(\mathrm{bpy})\right.$ (tppz) $]\left(\mathrm{CF}_{3} \mathrm{SO}_{3}\right)_{2}$, was readily isolated following ligand substitution at the chloro precursor in aqueous solutions, which is facilitated by the precipitation of $\mathrm{AgCl}$ in the presence of $\mathrm{Ag}^{+}$ions from $\mathrm{Ag}\left(\mathrm{CF}_{3} \mathrm{SO}_{3}\right){ }^{17,34}$ The cyclic and differential pulse voltammograms of $\left[\mathrm{Ru}\left(\mathrm{H}_{2} \mathrm{O}\right)(\mathrm{bpy})(\mathrm{tppz})\right]^{2+}$ in water at $\mathrm{pH} 6.8(0.1 \mathrm{M}$ phosphate buffer $)$ showed a single anodic/cathodic pair of waves with a mid potential of $0.64 \mathrm{~V}$ vs SCE (Figure 2). This single reversible process corresponds to the net $2 \mathrm{e}^{-} / 2 \mathrm{H}^{+}$oxidation from the $\left[\mathrm{H}_{2} \mathrm{O}-\mathrm{Ru}^{\mathrm{II}}\right]^{2+}$ to the $\left[\mathrm{O}=\mathrm{Ru}^{\mathrm{IV}}\right]^{2+}$ species, instead of the two typically separated $1 \mathrm{e}^{-} / 1 \mathrm{H}^{+}$steps in other complexes: ${ }^{45}$ $\mathrm{H}_{2} \mathrm{O}-\mathrm{Ru}^{\mathrm{II}}-\mathrm{e}^{-}, \mathrm{H}^{+} \rightarrow \mathrm{HO}-\mathrm{Ru}^{\mathrm{III}}-\mathrm{e}^{-}, \mathrm{H}^{+} \rightarrow \mathrm{O}=\mathrm{Ru}^{\text {IV }}$. This assignment was confirmed by comparison of Faradaic currents with the $\left[\mathrm{Ru}^{\mathrm{III}}(\mathrm{edta})(\mathrm{OH})\right]^{2-} /\left[\mathrm{Ru}^{\mathrm{II}}(\mathrm{edta})\left(\mathrm{H}_{2} \mathrm{O}\right)\right]^{2-}$

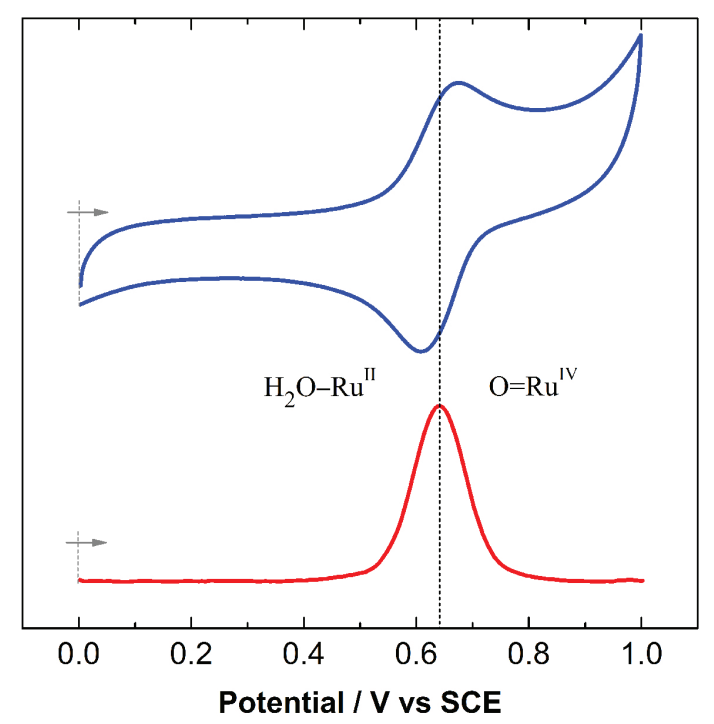

Figure 2. Cyclic (blue) and differential pulse (red) voltammograms of $\left[\mathrm{Ru}\left(\mathrm{H}_{\mathrm{x}} \mathrm{O}\right)(\mathrm{bpy})(\mathrm{tppz})\right]^{2+}$ in aqueous solution at $\mathrm{pH} 6.8(0.1 \mathrm{M}$ phosphate buffer); current intensities are arbitrarily normalized to facilitate comparative viewing of CV/DPV potential peaks. couple $\mathrm{e}^{46,47}$ (edta $=$ ethylenediaminetetraacetate) as reference for a monoelectronic redox process at identical experimental conditions.

As shown by the plot of $\mathrm{E}_{1 / 2}$ as a function of $\mathrm{pH}$ (Pourbaix diagram) in Figure 3, a Nernstian electrochemical behavior persists in acidic or basic environments within $\mathrm{pH}$ values 1-9, and the slope of a linear regression (blue line, with a drop of $57 \mathrm{mV}$ per $\mathrm{pH}$ unit) is consistent with a single $2 \mathrm{e}^{-} / 2 \mathrm{H}^{+}$process or two overlapping $1 \mathrm{e}^{-} / 1 \mathrm{H}^{+}$processes. ${ }^{48-50}$ This observation, which has also been recently made by Matias et al..$^{51,52}$ for other complexes, is attributed to the disproportionation of the relatively thermodynamically unstable hydroxo species $\left(2 \mathrm{HO}-\mathrm{Ru}^{\mathrm{III}} \rightarrow \mathrm{H}_{2} \mathrm{O}-\mathrm{Ru}^{\mathrm{II}}+\mathrm{O}=\mathrm{Ru}^{\mathrm{IV}}\right)$ as a consequence of electronic effects caused by strongly $\pi$-accepting ligands bearing the catalytic $\mathrm{Ru}-\mathrm{OH}_{\mathrm{x}}$ moiety. ${ }^{52}$

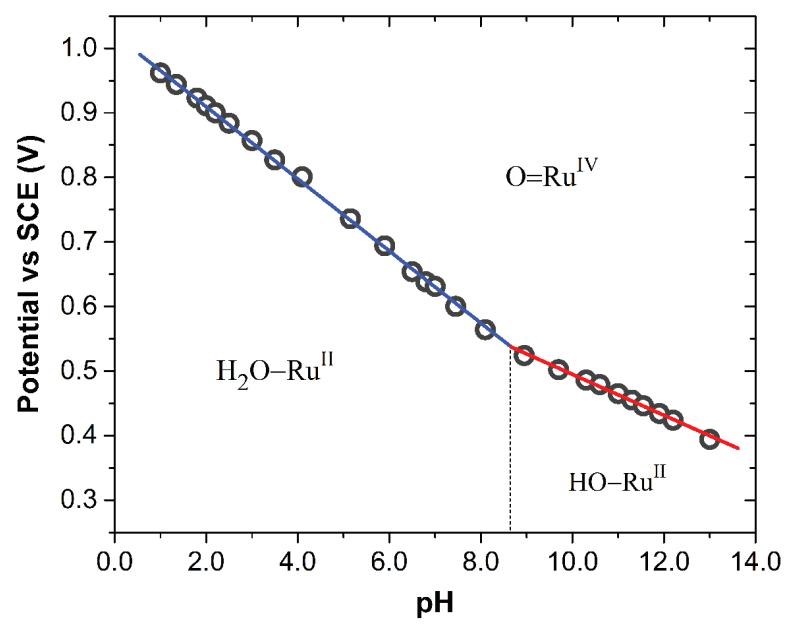

Figure 3. Pourbaix diagram for the complex $\left[\mathrm{Ru}\left(\mathrm{H}_{\mathrm{x}} \mathrm{O}\right)(\mathrm{bpy})(\mathrm{tppz})\right]^{2+}$ in aqueous solution ( $0.1 \mathrm{M}$ BR buffer); slopes of the fitted linear regressions in blue and red are $-57 \mathrm{mV} / \mathrm{pH}$ and $-33 \mathrm{mV} / \mathrm{pH}$, respectively.

Around $\mathrm{pH} 9$ and above, the clear change in the slope of the observed linear trend (red line, with a drop of $33 \mathrm{mV}$ per $\mathrm{pH}$ unit) reflects the deprotonation of the aquo species $\left(\mathrm{H}_{2} \mathrm{O}-\mathrm{Ru}^{\mathrm{II}} \rightarrow \mathrm{HO}-\mathrm{Ru}^{\mathrm{II}}+\mathrm{H}^{+}\right)$ consequently leading to a $2 \mathrm{e}^{-} / 1 \mathrm{H}^{+}$process ${ }^{48-50}$ at $\mathrm{pH}>9$ $\left(\mathrm{HO}-\mathrm{Ru}^{\mathrm{II}} \rightarrow \mathrm{O}=\mathrm{Ru}^{\mathrm{IV}}+2 \mathrm{e}^{-}+\mathrm{H}^{+}\right.$). The relatively low $\mathrm{p} K_{\mathrm{a}}$ value associated with the deprotonation of $\mathrm{H}_{2} \mathrm{O}-\mathrm{Ru}^{\text {II }}$ is taken at the intersection of the blue and red lines (ca. 8.6) and reflects the electronic effect on $\mathrm{Ru}^{\mathrm{II}}$ from the significantly stronger acceptor character of the bearing tppz ligand compared to tpy ( $\mathrm{p} K_{\mathrm{a}}$ ca. 9.7) ${ }^{53}$ Not surprisingly, the possible protonations of the oxidized species require highly acidic conditions (i.e., $\mathrm{p} K_{\mathrm{a}}<1$ ) and thus are clearly outside the $\mathrm{pH}$ window of the Pourbaix diagram.

The UV-Vis spectrum of $[\mathrm{RuCl}(\mathrm{bpy})(\mathrm{tppz})]^{+}$features a broad and intense band with $\lambda_{\max }$ at $506 \mathrm{~nm}$ (molar absorptivity $\left.(\varepsilon)=1.1 \times 10^{4} \mathrm{M}^{-1} \mathrm{~cm}^{-1}\right)$ in acetonitrile. Upon 
substitution of the chloride ligand in water, the corresponding absorption in $\left[\mathrm{Ru}\left(\mathrm{H}_{2} \mathrm{O}\right)(\mathrm{bpy})(\mathrm{tppz})\right]^{2+}$ is hypsochromically shifted to $\lambda_{\max }$ at $484 \mathrm{~nm}\left(\varepsilon=9.1 \times 10^{3} \mathrm{M}^{-1} \mathrm{~cm}^{-1}\right)$ in phosphate buffer, at pH 6.8 (Figure 4). As discussed further below, this strong absorption in the visible is a key spectral feature in the photocatalytic cycle of this complex and arises from the metal-to-ligand charge transfer (MLCT) transition predominantly involving the tridentate ligand moiety, $\mathrm{d} \pi\left(\mathrm{Ru}^{\mathrm{II}}\right) \rightarrow \pi^{*}(\mathrm{tppz})$ (Figures $\left.4, \mathrm{~S} 1-\mathrm{S} 2\right)$. Given that this MLCT absorption originates at the $\mathrm{d}_{\pi}^{6}$ configuration in $\mathrm{Ru}^{\mathrm{II}}$, it vanishes once the aquo species is oxidized into the $\mathrm{Ru}^{\mathrm{III}}$-hydroxo or $\mathrm{Ru}^{\mathrm{IV}}$-oxo states, which are essentially non-absorbing in the visible region. ${ }^{34,52}$

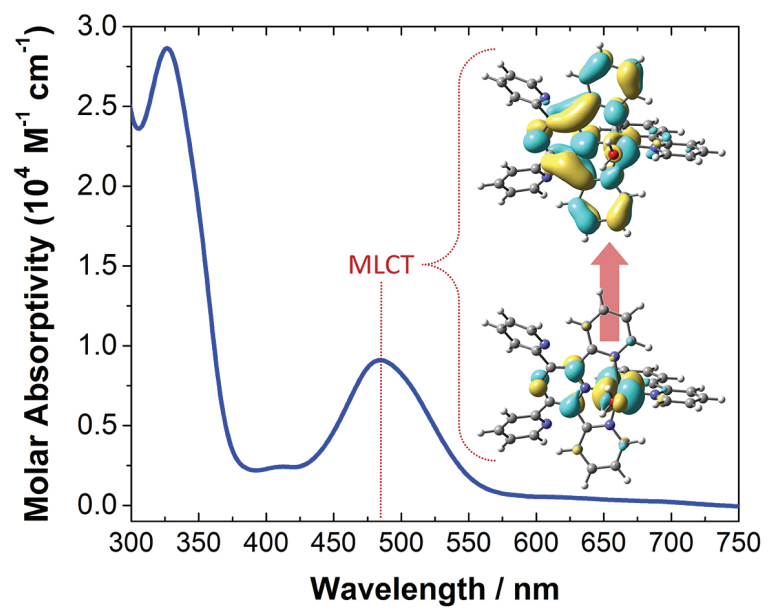

Figure 4. Absorption spectrum of the complex $\left[\mathrm{Ru}\left(\mathrm{H}_{2} \mathrm{O}\right)(\mathrm{bpy})(\mathrm{tppz})\right]^{2+}$ in water ( $\mathrm{pH}$ 6.8) focusing on the visible-region band, which is associated with the $\mathrm{Ru}^{\mathrm{II}} \rightarrow$ tppz transition (MLCT) as characterized via TD-DFT calculations and visually captured by the inset showing the corresponding "from $\rightarrow$ to" pair of natural transition orbitals (NTOs).

\section{Photocatalysis}

The photocatalytic tests were performed by exposing the sealed reaction vials to simulated visible-sunlight illumination $\left(\lambda_{\text {exc }}>400 \mathrm{~nm}\right.$ ) for $24 \mathrm{~h}$, at room temperature and pressure.$^{54}$ As with previous studies, ${ }^{16,17}$ the reaction system consisted of $0.02 \mathrm{mM}$ Ru complex, $10 \mathrm{mM}$ substrate, and $20 \mathrm{mM}$ acceptor in $5.0 \mathrm{~mL}$ of phosphate-buffered aqueous $\left(\mathrm{H}_{2} \mathrm{O}\right.$ or $\left.\mathrm{D}_{2} \mathrm{O}\right)$ solutions at $\mathrm{pH}$ 6.8. The chemically benign $\left[\mathrm{Co}^{\mathrm{III}}\left(\mathrm{NH}_{3}\right)_{5} \mathrm{Cl}\right] \mathrm{Cl}_{2}$ has become the commonly used electron acceptor in such experiments because, upon reduction $\left(\mathrm{E}_{\mathrm{red}}=-0.3 \mathrm{~V}\right.$ vs SCE) by an electron transfer from the photoexcited Ru complex, it undergoes fast and irreversible decomposition into $\left[\mathrm{Co}^{\mathrm{II}}\left(\mathrm{H}_{2} \mathrm{O}\right)_{6}\right]^{2+}$ (whose oxidation potential of about $+1.8 \mathrm{~V}$ is far too positive for the re-reduction of the oxidized $\mathrm{Ru}$ center) and therefore back electron transfer to the activated catalyst is prevented. ${ }^{16,55}$ The product of reaction was characterized by ${ }^{1} \mathrm{H}$ NMR spectroscopy and GC-MS analysis, as detailed in the Experimental section.
Benzyl alcohol was converted into benzaldehyde with a turnover number (TON) of $52 \pm 4$ cycles, which corresponds to an efficiency of $10-11 \%\left(\mathrm{TON}=\mathrm{n}_{\text {product }} / \mathrm{n}_{\text {catalyst }}\right.$; efficiency $\left.=\mathrm{n}_{\text {product }} / \mathrm{n}_{\text {substrate(initial) }}\right)$. With measurement uncertainty accounted for, this moderate performance is essentially the same as that previously demonstrated by the dinuclear [(tpy) $\left.\mathrm{Ru}(\mathrm{tppz}) \mathrm{Ru}\left(\mathrm{H}_{2} \mathrm{O}\right)(\mathrm{bpy})\right]^{4+}$ complex with 50 photocatalytic turnovers. ${ }^{17}$ Furthermore, the transformation of alcohol into aldehyde proved to be highly selective, with no formation of an over-oxidized product such as carboxylic acid.

Unlike supramolecular dyad constructs where a catalyst is judiciously paired with one or more designated lightharvesting units to promote stepwise buildup of higher oxidation states at the catalyst via sequential electrontransfer repeats (chromophore* $\rightarrow$ acceptor $\|$ catalyst $\rightarrow$ chromophore $^{+}$, this mononuclear complex becomes devoid of the initial MLCT-driven photoexcitation capability after the $\mathrm{H}_{2} \mathrm{O}-\mathrm{Ru}^{\mathrm{II}}$ species undergoes the first photoinduced electron transfer accompanying its oxidation to the HO-Ru ${ }^{\mathrm{III}}$ state. However, in view of the observed electrochemical behavior revealing a single $\mathrm{Ru}^{\mathrm{II}} / \mathrm{Ru}^{\mathrm{IV}}$ redox process, the active $\mathrm{O}=\mathrm{Ru}^{\mathrm{IV}}$ catalyst is rather formed by disproportionation of the electrochemically absent intermediate $\mathrm{HO}-\mathrm{Ru}^{\mathrm{III}}$ species following the photoexcited electron transfer from a tppz-centered ${ }^{3} \mathrm{MLCT}$ state (Figure S2) to the sacrificial acceptor. In the final chemical step, the catalytic $\mathrm{Ru}^{\mathrm{IV}}=\mathrm{O}$ state is reductively recycled to its chromophoric $\mathrm{H}_{2} \mathrm{O}-\mathrm{Ru}^{\mathrm{II}}$ state upon the selective $2 \mathrm{e}^{-} / 2 \mathrm{H}^{+}$dehydrogenative oxidation of benzyl alcohol into benzaldehyde. The overall photocatalytic cycle can be interpreted as depicted in Scheme 3.

While detailed kinetic and mechanistic studies are required to provide additional insights into each putative step of the global reaction, the formation of $\mathrm{O}=\mathrm{Ru} \mathrm{IV}^{\mathrm{IV}}$ as a consequence of $\mathrm{Ru}^{\mathrm{III}}$ disproportionation ${ }^{51,52,56}$ appears to be a key feature in the activation of this mononuclear catalyst. Although not previously explored in photocatalysis, such redox behavior has been observed in other $\mathrm{H}_{\mathrm{x}} \mathrm{O}-\mathrm{Ru}^{\mathrm{II}-\mathrm{IV}}$ systems and well elucidated in terms of electronic effects induced by the surrounding ligand environment. Generally, increasing the $\pi$-acceptor ability of an ancillary ligand results in additional stabilization of the $\mathrm{Ru}^{\mathrm{II}}$ species by $\mathrm{M}(\mathrm{d} \pi) \rightarrow \mathrm{L}\left(\mathrm{p} \pi^{*}\right)$ backbonding, while the multiple $\mathrm{Ru}=\mathrm{O}$ bond leads to stabilization of $\mathrm{Ru}^{\mathrm{IV}}$ by the oxo group. In the case of pyrazine-derivatives such as tppz or bpz, ${ }^{17,52}$ where the $\pi$-accepting character is so pronounced, this contrasting tendencies leading to increase of the $\mathrm{Ru}^{\mathrm{I} / \mathrm{III}}$ potential and decrease of the $\mathrm{Ru}^{\mathrm{III} / \mathrm{IV}}$ potential culminate with the coalescence of the two processes into a single $2 \mathrm{e}^{-} / 2 \mathrm{H}^{+}$ 


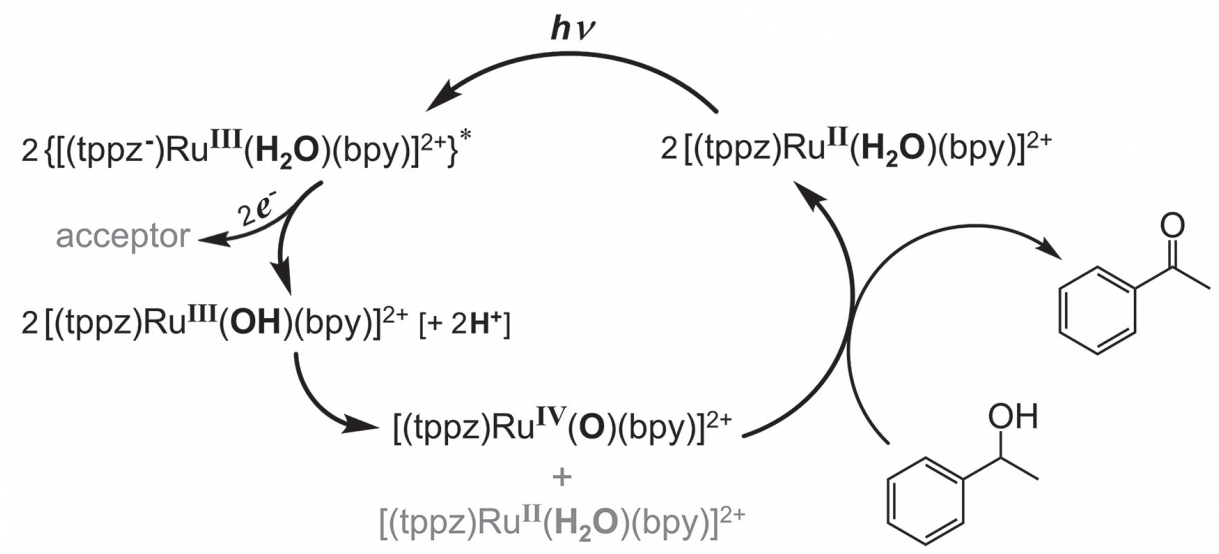

Scheme 3. Main steps underlying the photocatalytic dehydrogenative oxidation of benzyl alcohol into benzaldehyde by the mononuclear complex $\left[\mathrm{Ru}\left(\mathrm{H}_{2} \mathrm{O}\right)(\mathrm{bpy})(\mathrm{tppz})\right]^{2+}$ in water, at room conditions (RTP).

couple, as observed here for $\left[\mathrm{Ru}\left(\mathrm{H}_{\mathrm{x}} \mathrm{O}\right)(\mathrm{bpy})(\mathrm{tppz})\right]^{2+}$. Therefore, a one-electron (electrochemical or photochemical) oxidation of the starting $\mathrm{H}_{2} \mathrm{O}-\mathrm{Ru}^{\mathrm{II}}$ complex yields a $\mathrm{HO}-\mathrm{Ru}^{\mathrm{III}}$ species that is prone to disproportionation into the relatively more thermodynamically stable $\left\{\mathrm{H}_{2} \mathrm{O}-\mathrm{Ru}^{\mathrm{II}}+\mathrm{O}=\mathrm{Ru}^{\mathrm{IV}}\right\}$ pair. In cases where a stable $\mathrm{HO}-\mathrm{Ru}^{\mathrm{III}}$ state exists, its involvement in the oxidation of alcohols is also possible via cooperative intermolecular mechanisms involving multiple one-electron catalytic units; however, the process is typically too sluggish for significant contribution (hundreds of times slower than the corresponding $\mathrm{Ru}^{\mathrm{IV}}$-oxo species) ${ }^{57}$ and typically lacks the high selectivity of two-electron oxidants due to reaction pathways associated with radical species. A mechanistic aspect pertinent to further investigations is the complementary understanding of possible factors limiting or enhancing efficiency, such as the reported observation of $\mathrm{N}$-oxide bond formation by oxygen atom transfer to noncoordinating as well as coordinating pyridyl nitrogens in different examples of mononuclear Ru catalysts under conditions conducive to water oxidation..$^{58-62}$

\section{Conclusions}

Light-driven catalytic activity by the mononuclear complex $\left[\mathrm{Ru}\left(\mathrm{H}_{2} \mathrm{O}\right)(\mathrm{bpy})(\mathrm{tppz})\right]^{2+}$ toward the 2-electron/2-proton dehydrogenative oxidation of a representative benzyl alcohol has been observed in water at room conditions. The overall photocatalytic reaction turnover, efficiency, and selectivity shown by this mononuclear species were comparable to those of the synthetically more elaborated dinuclear complex [(tpy) $\left.\mathrm{Ru}(\mathrm{tppz}) \mathrm{Ru}\left(\mathrm{H}_{x} \mathrm{O}\right)(\mathrm{bpy})\right]^{4+} .{ }^{17}$ This somewhat surprising activity is attributed to the fortuitous formation of the catalytic $\mathrm{O}=\mathrm{Ru}^{\mathrm{IV}}$ state (along with $\mathrm{H}_{2} \mathrm{O}-\mathrm{Ru}^{\mathrm{II}}$ ) by redox disproportionation of the elusive $\mathrm{HO}-\mathrm{Ru}^{\text {III }}$ species following photoinduced electron transfer to an acceptor upon visible-light absorption by $\left[\mathrm{Ru}\left(\mathrm{H}_{2} \mathrm{O}\right)(\mathrm{bpy})(\mathrm{tppz})\right]^{2+}$, whose proton-coupled electrochemical behavior in water was demonstrated in a wide $\mathrm{pH}$ range. Although indicative of a performance too moderate for practical applications, this finding is relevant to furthering the basic understanding of structural/electronic effects in the design of synthetically viable (photo)catalysts toward environmentally and economically attractive chemical technologies based on carbon-neutral utilization of solar energy, water, and possibly $\mathrm{O}_{2}$ as the ultimate oxidant ${ }^{63,64}$ in the green aerobic oxidation chemistry of organic substrates of fundamental importance in laboratory and industry.

\section{Supplementary Information}

Supplementary information is available free of charge at https://jbcs.sbq.org.br as PDF file.

Crystallographic data (excluding structure factors) for the structure in this work was deposited in the Cambridge Crystallographic Data Centre as supplementary publication number CCDC 2008410. Copies of the data can be obtained, free of charge, via https://www.ccdc.cam.ac.uk/ structures/.

\section{Acknowledgments}

This work was supported by the U.S. Department of Energy (DOE) through the Laboratory Directed Research and Development (LDRD) program at Los Alamos National Laboratory.

\section{References}

1. Nocera, D. G.; Acc. Chem. Res. 2017, 50, 616.

2. Armaroli, N.; Balzani, V.; Chem.- Eur. J. 2016, 22, 32. 
3. Berardi, S.; Drouet, S.; Francas, L.; Gimbert-Surinach, C.; Guttentag, M.; Richmond, C.; Stoll, T.; Llobet, A.; Chem. Soc. Rev. 2014, 43, 7501.

4. Harriman, A.; Philos. Trans. R. Soc., A 2013, 371, 20110415.

5. Lewis, N. S.; Nocera, D. G.; Proc. Natl. Acad. Sci. USA 2006, 103, 15729.

6. Centi, G.; Perathoner, S.; ChemSusChem 2010, 3, 195.

7. Ravelli, D.; Dondi, D.; Fagnoni, M.; Albini, A.; Chem. Soc. Rev. 2009, 38, 1999.

8. Sheldon, R. A.; Arends, I.; Hanefeld, U.; Green Chemistry and Catalysis; Wiley-VCH: Weinheim, Germany, 2007.

9. Herrero, C.; Quaranta, A.; Leibl, W.; Rutherford, A. W.; Aukauloo, A.; Energy Environ. Sci. 2011, 4, 2353.

10. Li, F.; Jiang, Y.; Zhang, B.; Huang, F.; Gao, Y.; Sun, L.; Angew. Chem., Int. Ed. 2012, 51, 2417.

11. Chao, D.; Fu, W.-F.; Chem. Commun. 2013, 49, 3872.

12. Ohzu, S.; Ishizuka, T.; Hirai, Y.; Fukuzumi, S.; Kojima, T.; Chem.- Eur. J. 2013, 19, 1563.

13. Chao, D.; Fu, W.-F.; Dalton Trans. 2014, 43, 306.

14. Ashford, D. L.; Gish, M. K.; Vannucci, A. K.; Brennaman, M. K.; Templeton, J. L.; Papanikolas, J. M.; Meyer, T. J.; Chem. Rev. 2015, 115, 13006.

15. Hennessey, S.; Farras, P.; Benet-Buchholz, J.; Llobet, A.; Catal. Sci. Technol. 2019, 9, 6760.

16. Chen, W.; Rein, F. N.; Rocha, R. C.; Angew. Chem., Int. Ed. 2009, 48, 9672.

17. Chen, W.; Rein, F. N.; Scott, B. L.; Rocha, R. C.; Chem.- Eur. J. 2011, 17, 5595.

18. Pho, T. V.; Sheridan, M. V.; Morseth, Z. A.; Sherman, B. D.; Meyer, T. J.; Papanikolas, J. M.; Schanze, K. S.; Reynolds, J. R.; ACS Appl. Mater. Interfaces 2016, 8, 9125.

19. Farras, P.; di Giovanni, C.; Clifford, J. N.; Palomares, E.; Llobet, A.; Coord. Chem. Rev. 2015, 304, 202.

20. Sheldon, R. A.; Kochi, J. K.; Metal-Catalyzed Oxidations of Organic Compounds; Academic Press: New York, NY, USA, 1981.

21. Hudlicky, M.; Oxidations in Organic Chemistry; American Chemical Society: Washington, DC, USA, 1990.

22. Tojo, G.; Fernandez, M.; Oxidation of Alcohols to Aldehydes and Ketones; Springer Science: New York, NY, USA, 2006.

23. APEX II, v. 7.0; Bruker AXS Inc., Madison, WI, USA, 2009.

24. SAINT+, v. 7.66a; Bruker AXS Inc., Madison, WI, USA, 2009.

25. Sheldrick, G. M.; SADABS, v. 2.03; University of Göttingen, Germany, 2008.

26. Sheldrick, G. M.; Acta Cryst. 2008, A64, 112.

27. Frisch, M. J.; Trucks, G. W.; Schlegel, H. B.; Scuseria, G. E.; Robb, M. A.; Cheeseman, J. R.; Scalmani, G.; Barone, V.; Petersson, G. A.; Nakatsuji, H.; Li, X.; Caricato, M.; Marenich, A. V.; Bloino, J.; Janesko, B. G.; Gomperts, R.; Mennucci, B.; Hratchian, H. P.; Ortiz, J. V.; Izmaylov, A. F.; Sonnenberg, J. L.; Williams-Young, D.; Ding, F.; Lipparini, F.; Egidi, F.;
Goings, J.; Peng, B.; Petrone, A.; Henderson, T.; Ranasinghe, D.; Zakrzewski, V. G.; Gao, J.; Rega, N.; Zheng, G.; Liang, W.; Hada, M.; Ehara, M.; Toyota, K.; Fukuda, R.; Hasegawa, J.; Ishida, M.; Nakajima, T.; Honda, Y.; Kitao, O.; Nakai, H.; Vreven, T.; Throssell, K.; Montgomery Jr., J. A.; Peralta, J. E.; Ogliaro, F.; Bearpark, M. J.; Heyd, J. J.; Brothers, E. N.; Kudin, K. N.; Staroverov, V. N.; Keith, T. A.; Kobayashi, R.; Normand, J.; Raghavachari, K.; Rendell, A. P.; Burant, J. C.; Iyengar, S. S.; Tomasi, J.; Cossi, M.; Millam, J. M.; Klene, M.; Adamo, C.; Cammi, R.; Ochterski, J. W.; Martin, R. L.; Morokuma, K.; Farkas, O.; Foresman, J. B.; Fox, D. J.; Gaussian 16, Revision C.01, Gaussian, Inc., Wallingford, CT, USA, 2019.

28. Becke, A. D.; J. Chem. Phys. 1993, 98, 5648.

29. Stephens, P. J.; Devlin, F. J.; Chabalowski, C. F.; Frisch, M. J.; J. Chem. Phys. 1994, 98, 11623.

30. Dolg, M.; Wedig, U.; Stoll, H.; Preuss, H.; J. Chem. Phys. 1987, $86,866$.

31. Krishnan, R.; Binkley, J. S.; Seeger, R.; Pople, J. A.; J. Chem. Phys. 1980, 72, 650.

32. Clark, T.; Chandrasekhar, J.; Spitznagel, G. W.; Schleyer, P. V. R.; J. Comput. Chem. 1983, 4, 294.

33. Jakubikova, E.; Chen, W.; Dattelbaum, D. M.; Rein, F. N.; Rocha, R. C.; Martin, R. L.; Batista, E. R.; Inorg. Chem. 2009, 48, 10720.

34. Matias, T. A.; Mangoni, A. P.; Toma, S. H.; Rein, F. N.; Rocha, R. C.; Toma, H. E.; Araki, K.; Eur. J. Inorg. Chem. 2016, 5547.

35. Casida, M. E.; Jamorski, C.; Casida, K. C.; Salahub, D. R.; J. Chem. Phys. 1998, 108, 4439.

36. Stratmann, R. E.; Scuseria, G. E.; Frisch, M. J.; J. Chem. Phys. 1998, 109, 8218.

37. Tomasi, J.; Mennucci, B.; Cammi, R.; Chem. Rev. 2005, 105, 2999.

38. Scalmani, G.; Frisch, M. J.; J. Chem. Phys. 2010, 132, 114110.

39. Dennington, R.; Keith, T. A.; Millam, J. M.; GaussView 6, Semichem Inc., Shawnee Mission, KS, USA, 2016.

40. Rein, F. N.; Chen, W.; Scott, B. L.; Rocha, R. C.; Acta Crystallogr., Sect. E: Crystallogr. Commun. 2018, E74, 1250.

41. Rocha, R. C.; Rein, F. N.; Jude, H.; Shreve, A. P.; Concepcion, J. J.; Meyer, T. J.; Angew. Chem., Int. Ed. 2008, 47, 503.

42. Rein, F. N.; Chen, W.; Scott, B. L.; Rocha, R. C.; Acta Crystallogr., Sect. E: Crystallogr. Commun. 2015, E71, 1017.

43. Chen, W.; Rein, F. N.; Scott, B. L.; Rocha, R. C.; Acta Crystallogr., Sect. E: Crystallogr. Commun. 2013, E69, m79.

44. Jude, H.; Scott, B. L.; Rocha, R. C.; Acta Crystallogr., Sect. E: Crystallogr. Commun. 2013, E69, m81.

45. Ishizuka, T.; Kotani, H.; Kojima, T.; Dalton Trans. 2016, 45, 16727.

46. Rein, F. N.; Rocha, R. C.; Toma, H. E.; Quim. Nova 2004, 27 , 106.

47. Rocha, R. C.; Rein, F. N.; Toma, H. E.; Inorg. Chem. Commun. $\mathbf{2 0 0 2}, 5,891$. 
48. Slattery, S. J.; Blaho, J. K.; Lehnes, J.; Goldsby, K. A.; Coord. Chem. Rev. 1998, 174, 391.

49. Rocha, R. C.; Rein, F. N.; Toma, H. E.; J. Braz. Chem. Soc. 2001, 12, 234.

50. Costentin, C.; Chem. Rev. 2008, 108, 2145.

51. Matias, T. A.; Parussulo, A. L. A.; Benavides, P. A.; Guimarães, R. R.; Dourado, A. H. B.; Nakamura, M.; de Torresi, S. I. C.; Bertotti, M.; Araki, K.; Electrochim. Acta 2018, 283, 18.

52. Matias, T. A.; Rein, F. N.; Rocha, R. C.; Formiga, A. L. B.; Toma, H. E.; Araki, K.; Dalton Trans. 2019, 48, 3009.

53. Takeuchi, K. J.; Thompson, M. S.; Pipes, D. W.; Meyer, T. J.; Inorg. Chem. 1984, 23, 1845.

54. Bowen, B. M.; Los Alamos Climatology, LANL Report LA-11735-MS; Los Alamos National Laboratory: Los Alamos, NM, USA, 1990. Available at https://www.osti.gov/ biblio/6950999-los-alamos-climatology accessed in July 2020.

55. Lehn, J.-M.; Sauvage, J.-P.; Ziessel, R.; New J. Chem. 1979, 3, 423.

56. Nunes, G. S.; Alexiou, A. D. P.; Araki, K.; Formiga, A. L. B.; Rocha, R. C.; Toma, H. E.; Eur. J. Inorg. Chem. 2006, 1487.
57. Thompson, M. S.; DeGiovani, W. F.; Moyer, B. A.; Meyer, T. J.; J. Org. Chem. 1984, 49, 4972.

58. Ertem, M. Z.; Concepcion, J. J.; Inorg. Chem. 2020, 59, 5966.

59. Ravari, A. K.; Zhu, G.; Ezhov, R.; Pineda-Galvan, Y.; Page, A.; Weinschenk, W.; Yan, L.; Pushkar, Y.; J. Am. Chem. Soc. 2019, $142,884$.

60. Wang, Y.; Rinkevicius, Z.; Ahlquist, M. S. G.; Chem. Commun. $\mathbf{2 0 1 7}, 53,5622$.

61. Liu, Y.; Ng, S. M.; Yiu, S. M.; Lam, W. W. Y.; Wei, X. G.; Lau, K. C.; Lau, T. C.; Angew. Chem., Int. Ed. 2014, 53, 14468.

62. Wasylenko, D. J.; Ganesamoorthy, C.; Koivisto, B. D.; Henderson, M. A.; Berlinguette, C. P.; Inorg. Chem. 2010, 49, 2202.

63. Zhang, X.; Rakesh, K. P.; Ravindar, L.; Qin, H.-L.; Green Chem. 2018, 20, 4790.

64. Campbell, A. N.; Stahl, S. S.; Acc. Chem. Res. 2012, 45, 851.

Submitted: June 6, 2020

Published online: August 10, 2020 